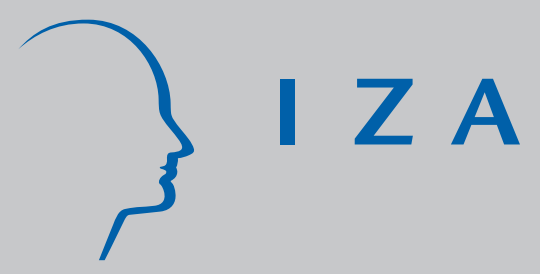

IZA DP No. 425

Successful Apprenticeship-to-Work Transitions: On the Long-Term Change in Significance of the German School-Leaving Certificate

Felix Büchel

February 2002 


\title{
Successful Apprenticeship-to-Work Transitions: On the Long-Term Change in Significance of the German School-Leaving Certificate
}

\author{
Felix Büchel \\ Max Planck Institute for Human Development, Berlin, DIW Berlin, \\ Technical University of Berlin and IZA, Bonn
}

Discussion Paper No. 425

February 2002

\author{
IZA \\ P.O. Box 7240 \\ D-53072 Bonn \\ Germany \\ Tel.: +49-228-3894-0 \\ Fax: +49-228-3894-210 \\ Email: iza@iza.org
}

This Discussion Paper is issued within the framework of IZA's research area The Welfare State and Labor Markets. Any opinions expressed here are those of the author(s) and not those of the institute. Research disseminated by IZA may include views on policy, but the institute itself takes no institutional policy positions.

The Institute for the Study of Labor (IZA) in Bonn is a local and virtual international research center and a place of communication between science, politics and business. IZA is an independent, nonprofit limited liability company (Gesellschaft mit beschränkter Haftung) supported by the Deutsche Post AG. The center is associated with the University of Bonn and offers a stimulating research environment through its research networks, research support, and visitors and doctoral programs. IZA engages in (i) original and internationally competitive research in all fields of labor economics, (ii) development of policy concepts, and (iii) dissemination of research results and concepts to the interested public. The current research program deals with (1) mobility and flexibility of labor, (2) internationalization of labor markets, (3) the welfare state and labor markets, (4) labor markets in transition countries, (5) the future of labor, (6) evaluation of labor market policies and projects and (7) general labor economics.

IZA Discussion Papers often represent preliminary work and are circulated to encourage discussion. Citation of such a paper should account for its provisional character. A revised version may be available on the IZA website (www.iza.org) or directly from the author. 
IZA Discussion Paper No. 425

February 2002

\section{ABSTRACT}

\section{Successful Apprenticeship-to-Work Transitions: On the Long-Term Change in Significance of the German School-Leaving Certificate*}

The quality of labor-market entry achieved by newly qualified apprentices in West Germany is analyzed from 1948 to 1992. A bivariate probit model, using data from the BIBB/IAB employment survey, is applied to estimate simultaneously the quality of the school-toapprenticeship transition and that of the apprenticeship-to-work transition. This shows that school leavers with lower levels of general education are selected into apprenticeships with less favorable employment prospects in all analyzed time periods. However, when controlling for this selection effect, it is only in the most recent period that lower academic achievers are further penalized for the shortcomings in their general education at the apprenticeship-towork transition. Furthermore, the crowding-out of trainees with lower levels of general education can be observed in both the less demanding and the more challenging occupational fields.

JEL Classification: $\quad$ I21, J21, J24, J44, J62

Keywords: School-to-work transition, human capital components, apprenticeship system

Felix Büchel

Max Planck Institute for Human Development

Lentzeallee 94

D-14195 Berlin

Germany

Tel.: +493082406427

Fax: +49 30-824 9939

Email: buechel@mpib-berlin.mpg.de

\footnotetext{
* Paper prepared for presentation at the IZA Workshop "Apprenticeship Training: A Model for the Future?", November 9-10, 2001, Bonn, Germany. Earlier versions of this paper have been presented at the Federal Employment Service's Institute for Employment Research IAB, Nuremberg, July 27, 2001, and the International Conference "Transitions," jointly organized by the Swiss Educational Research Association SGBF and the Swiss Association for Teacher Education SGL, October 4-6, 2001, Aarau (Switzerland).
} 


\section{Successful Apprenticeship-to-Work Transitions:}

\section{On the Long-Term Change in Significance of the German School-Leaving Certificate}

\section{Background and Research Questions}

The German dual system of vocational education has long been regarded as an exceptionally successful institution. The system affords young people leaving the general education system the opportunity to learn a trade or profession in an apprenticeship lasting several years. The term "dual" reflects the specific nature of this form of training - in addition to the practical skills acquired in onthe-job training, students spend one or two days a week at vocational school, where they acquire the necessary theoretical background knowledge (for an overview of the institutional organization of this system, see Tessaring 1993, Soskice 1994, Franz/Soskice 1995, Müller et al. 1998: 144ff, Neubäumer 1999).

The success of this type of training program for young people who do not wish to continue their education in the purely academic context is confirmed by numerous indicators, including the youth unemployment rate in international comparison (OECD 2000). This positive evaluation of the system is validated even by more complex indicators (Büchtemann et al. 1994, Winkelmann 1996). Indeed, the altogether very favorable image of the German "dual system" has prompted a number of countries - including the USA (see Harhoff/Kane 1997, Gitter/Scheuer 1997, Hamilton/Hamilton 1999) - to endeavor to adopt a similar approach. Most EU countries now offer corresponding forms of apprenticeship program, albeit with differing levels of priority (cf. Ní Cheallaigh 1995).

Recently, however, a growing body of opinion in Germany has been predicting a rather bleak future for the dual system of vocational education. Two secular trends present serious problems for the institution. First, job requirements are increasing rapidly as a result of the accelerating technological progress. This raises the question of whether instructors - particularly those working in the vocational schools - are in a position to react quickly enough and adapt the contents of the training programs to the new conditions. Second, the question arises of whether the apprentices are at all capable of satisfying the constantly increasing job requirements. This central problem is further compounded by the sustained expansion of the German education system since the late 1960s: An increasing proportion of those school leavers who, by reason of their social background, would formerly have been most likely to take up an apprenticeship, now have access to higher education. This means that, compared to the past, there is negative selection of the school leavers entering apprenticeships. As yet, the effects of these two mutually dependent and intersecting secular trends on the efficiency of the dual system - measured in terms of the employment prospects of the appren- 
tices it produces - have only been investigated in rather rudimentary form; only very few sociological studies are available (Blossfeld 1988, Handl 1996, Konietzka 1999).

In this presentation, the employment prospects of recently qualified trainees will be operationalized in a proxy approach, based on the quality of their labor-market entry. The questions to be addressed are as follows: Have the employment prospects of newly qualified trainees deteriorated over the course of time? Does this hold especially for trainees with a poor level of general education or trainees in particular occupational groups? Furthermore, does the pattern of results hold when taking into account that disproportionate numbers of young adults with a poor educational background have always been selected into apprenticeships with poor employment prospects? Finally, are potential changes in the occupational risks of trainees with low levels of general education to be observed in the more demanding or in the less challenging occupational fields?

\section{Methodology}

\section{Data and Case Selection}

The empirical analyses are based on data from the BIBB/IAB employment survey. This data set was gathered by the Federal Institute for Vocational Training BIBB, Berlin, in collaboration with the Federal Employment Service's Institute for Employment Research IAB, Nuremberg. It is representative for Germany and contains retrospective information on the educational and occupational careers of approximately 34,000 residents of West and East Germany. Following surveys in 1979, $1985 / 86$ and 1991/92, the most recent wave of the survey was conducted in 1998/99. Because the data from the latest wave of the survey has not yet been released to the public, the present study is based on data from the 1991/92 wave (for details of this database, see Jansen/Stooß 1993, p. 7ff. and p. 163ff.). The stark differences in the labor market structures of West and East Germany over the entire postwar era make it necessary for the two areas to be analyzed separately. As such, the present analysis is restricted to West Germany. The BIBB/IAB survey was restricted to members of the economically active population, ${ }^{1}$ with non-Germans being surveyed only if they had an adequate command of the German language. As the latter kind of restriction entails obvious methodological problems, non-German respondents are excluded from the present analyses.

\footnotetext{
$1 \quad$ Restricting the parent population to economically active respondents constitutes a systematic selection of trainees that should be taken into account when interpreting the results.
} 
In the present study, the focus is on all those who have completed an apprenticeship. In the interests of homogeneity, the analyses are restricted to those who served their apprenticeship in the postwar era. Accordingly, only those who gained their apprenticeship qualification between 1948 and 1992 are included in the analyses. For the same reason, the few individuals who served an apprenticeship after completing a higher education degree are also excluded from the analyses.

\section{Phase of Transition}

Irrespective of the particular training system, the course of the future career path is largely determined by the quality of labor-market entry (see, e.g., Inkmann et al. 1998, Burgess et al. 1999, Klotz et al. 2000). Accordingly, the phase of transition from the apprenticeship to the world of work has always been of particular interest to educational and labor market researchers (Palamidis/Schwarze 1989, Büchel 1994, Helberger et al. 1994, Büchel/Neubäumer forthcoming; for an international perspective, see Shavit/Müller 1998, Gangl 2000; for an overview of current research questions, see Raffe 1997). A central advantage of this approach is that the effects of age and occupational experience are essentially neutralized, making it possible for cohort or period effects to be isolated (see, e.g., Blossfeld 1985). In the data set under analysis, respondents were asked the following question: "How did you fare immediately after your apprenticeship?" All respondents who belonged to the economically active population "immediately" after completing their vocational training (employed and unemployed respondents; the latter category including those who "only had a casual job") were taken into consideration. In other words, respondents who were neither employed nor actively looking for a job "immediately" after completing their apprenticeship, but were in further education, serving a voluntary social year, doing their military/community service, or in voluntary unemployment were not included in the analyses.

\section{Definition of a Successful Apprenticeship-to-Work Transition}

Those respondents who stated that they were unemployed or only had a casual job immediately after completing their apprenticeship were classified as "unsuccessful." The question of whether the dual system accomplishes its goal of preparing apprentices for specific occupations was also considered: Those who stated that they "found a job immediately, but not one corresponding to (their) qualifications," were classified as "unsuccessful" in terms of their - assumed - ambition to serve an apprenticeship that would later secure them an appropriate position in which their skills were fully utilized (for further information on the concept of overeducation, see Büchel 2001). The group 
deemed to be "successful" thus contained those who stated that they found a job corresponding to their qualifications immediately after completing their apprenticeship.

\section{Periods of Observation}

To allow for the identification of cohort or period effects, the total period of observation (19481992) was subdivided into three shorter periods. This division was made on the basis of the economic conditions prevailing in West Germany in each of the periods. The initial postwar period (1948-1959) was characterized by normalization and decreasing unemployment figures. This was followed by a second phase (1960-1975), with a booming economy and low unemployment. The third and final phase (1976-1992) was marked by mounting economic difficulties and growing unemployment rates; at the same time, the effects of the imposed expansion of the education system started to become apparent. All of the following analyses were conducted for each period separately.

\section{Analysis Procedure}

In a first descriptive step, highly aggregated frequency distributions, broken down by time period only, were computed for the respondents' employment status immediately after completing their apprenticeship (Table 1). In a second descriptive step, this information was broken down according to school-leaving certificate and gender (Table 2). For the sake of clarity, data on the school-leaving certificate was condensed into two categories: "poor education" (Hauptschule certificate or no qualifications at all) and "good education" (Realschule certificate or above).

Following this, the results presented in Table 2 were re-examined in a multivariate approach. For each period, binary probit models (cf. Greene 2000: 812ff.) were used to identify factors impacting on the quality of the apprenticeship-to-work transition (Table 3). Because systematic correlations were expected between the school-leaving certificate and gender, these two central variables were controlled in the form of interaction terms. The following additional control variables were also entered in the equation: occupational field of the apprenticeship (aggregated into 13 groups, with the broad group of the metalworking occupations serving as the reference category), the size of the

2 When interpreting these results, it is important to bear in mind that this proxy approach is based on a short period in the lives of the respondents: Transitions from an apprenticeship to an adequate position occurring only after a transitional period of unemployment, casual work, or skill mismatch are categorized as "unsuccessful," even though the respondent may subsequently have found a position corresponding to his or her skills within a very short period of time. 
firm providing the apprenticeship training, whether the respondent served the apprenticeship in a firm authorized to provide apprenticeship training or in a public financed training center ("external training"), the sector of the firm providing the training (public sector: yes/no), the duration of the apprenticeship in years, and the unemployment rate at the time the newly qualified apprentice entered the labor market.

In a next step, account was taken of the fact that gender and schooling correlate systematically with the choice of apprenticed trade/profession (see, e.g., Kühn/Zinn 1998). Using a bivariate probit model (cf. Greene 2000: 849ff.), the analysis described above was replicated, this time controlling in a second equation for the relationship between gender, schooling, and the choice of an apprenticeship with "poor" employment prospects (Table 4). dered according to the quality of the later apprenticeship-to-work transition, and the sample then split into two parts of similar size. ${ }^{-1}$ In addition, account was taken of information already available from Table 3, namely that trainees who do not serve their apprenticeship in a firm authorized to provide training have systematically lower chances of realizing a successful transition to the world of work. Serving an apprenticeship in an authorized firm was thus taken as an additional criterion for an "apprenticeship with good employment prospects".

In a final step in the analysis, it was investigated whether or not the pattern of results presented in Table 3 for the total sample in each period holds when considering only occupations with "good" or "bad" employment prospects. After splitting the sample accordingly, the analysis performed in Table 3 was replicated for each of these subgroups (Table 5).

3 The distribution of the covariates is documented in Table A1 in the Appendix.

4 These results are not presented in table form; information on the classification of occupations is provided in the notes to Table 4.

5 Accordingly, the cases are not distributed equally between apprenticeships with "good" and "poor" employment prospects.

6 The reference categories used in the analysis of the apprenticed trades/professions were as follows: For occupations with "poor" employment prospects: the metalworking occupations, which scored relatively low in all time periods; for occupations with "good" employment prospects: clerical occupations in banks, insurance companies, and public administration, which scored relatively high in all time periods. 


\section{Empirical Results}

\section{Descriptive Results}

Table 1 contains the employment status distribution of those respondents who belonged to the economically active population immediately after completing their apprenticeship. This first highly aggregated analysis is broken down by the year the apprenticeship was completed only.

-- please insert Table 1 about here --

The results confirm that the German dual system of vocational education has operated at a consistently high level of efficiency over an extended period of time. Newly qualified trainees in search of work were almost entirely absorbed by the labor market throughout the entire postwar era. However, some of those who realized a seamless apprenticeship-to-work transition did have to accept a position for which they were overqualified. The proportion of those entering the labor market with this sort of skill mismatch accounted for about one-tenth of the respondents throughout the period of investigation. On the general level, it can thus be concluded that the dual system does indeed achieve its goal of enabling young adults to enter the labor market. However, the system does not appear to live up to its more specific - and assumed - goal of providing young adults with vocational qualifications that can be fully exploited on the labor market - not immediately, at least. In this respect, a notable proportion of the apprenticeship-to-work transitions must be regarded as "unsuccessful." Although the rate of unemployment among new entrants to the labor force has risen noticeably from one to four percentage points since 1975 , it is still very low. $\square$ When interpreting these - on the whole very encouraging - results, it is important to bear in mind that the respondents who provided them belonged to the economically active population at the time the survey was conducted; in other words, that the sample itself is the result of positive selection. On the other hand, the results would not necessarily be very different if the sample had been less specific. This would only be the case if those who were not able to realize a successful apprenticeship-to-work transition immediately after completing their apprenticeship (despite being willing to work), reacted by systematically - and to a large extent permanently - withdrawing from the labor force.

In Table 2, the two categories of respondents who were "unemployed" or in an "overqualified position" immediately after completing their apprenticeship are collapsed into a single category, and compared with those who realized a "successful" transition to an adequate position. In addition, the

7 It should also be noted that these figures include respondents with casual jobs; the actual rate of unemployment is thus even lower than indicated. 
results are broken down according to gender and the quality of the school-leaving certificate acquired prior to the apprenticeship; at this stage in the analysis, no differentiation is made for the type of apprenticeship chosen. Here again, the focus is on changes to be observed over time.

-- please insert Table 2 about here --

Even when broken down according to schooling and gender, the results bear out a remarkable stability in the quality of the apprenticeship-to-work transition throughout the entire period of investigation. In almost all categories, around $90 \%$ of the trainees realized an optimal transition to the world of work. A noticeable exception can be discerned in the most recent period of observation (1975-1992), however, where there is a sharp drop in the success rate of those trainees with a poor level of general education (Hauptschule certificate or no school-leaving certificate at all), falling to just over $80 \%$. Gender-specific differences are negligible here.

\section{Control for Apprenticed Trade and Other Characteristics}

In the next step, it was tested whether the deterioration in the employment prospects of trainees with low levels of schooling (see Table 2) holds when controlling for the apprenticed trade/profession, the structure of the firm providing the apprenticeship training, and the labor market situation at the time the apprenticeship was completed.

-- please insert Table 3 about here --

The results presented in Table 3 substantiate the descriptive findings: It was only in the most recent period of observation that a low level of schooling began to represent a risk factor at the apprenticeship-to-work transition. Men and women were hit equally by this development. In the time from 1948 to 1975 , in contrast, the quality of general schooling acquired prior to the apprenticeship did not have any effect on the probability of realizing an optimal transition. It is striking that this result holds even when controlling for the diverse apprenticeships with varying employment prospects, and for the structure of the firms providing the apprenticeship training.

With respect to the control variables, it emerges that - relative to the group of metalworking occupations - the initial period of postwar reconstruction in West Germany (1948-1959) was a particularly advantageous time for newly qualified apprentices in the primary sector, construction workers, carpenters, and painters. Other than this, the chances of realizing a seamless apprenticeship-to-work 
transition were more or less equal across the various trades and professions. In the boom period (1960-1974), occupation-specific differences in transition prospects became more clear cut as structural change in the labor market became apparent. The prospects of those in the metalworking occupations - still a broad occupational group - began to deteriorate. Although construction workers were still in demand, as were other manufacturers and technicians, there was now an increased demand for health care assistants and for clerical workers in banks, insurance companies, and public administration. Moreover, a longer period of apprenticeship now had a positive effect. In the most recent period of investigation, consolidation of the structural change can be observed. Only respondents in the more qualified, non-manual occupations (health care occupations and clerical positions in banks, insurance companies, and public administration) had above-average chances of realizing a smooth apprenticeship-to-work transition. Moreover, serving an apprenticeship in a small firm with less than ten employees began to have a detrimental effect. For the first time, a relationship emerged between the prevailing economic conditions and the chances of successful labor-market entry; this effect was rather weak, however. The only common feature in all three periods of investigation is that trainees who did not complete their apprenticeship in a firm authorized to provide training (i.e., who attended "external training" in public financed training center) had far less auspicious prospects than their counterparts who did serve their apprenticeship in such a company. This reflects the lack of practical on-the-job training of the latter group; a deficit which prevents these apprentices from accumulating company-specific human capital. This is worthy of note, as a large proportion of those trained in the dual system are hired by the firm they trained at after completing their apprenticeship.

\section{Control for Selective Admission to Certain Apprenticeships}

In the next step of the analysis, account was taken of the fact that the choice of apprenticed trade is largely determined by the level of general education attained by the school leavers competing for apprenticeships. Accordingly, it can be assumed that if we omit to control for this systematic selection at the school-to-apprenticeship transition (first threshold), the schooling effect yielded by the analysis of the apprenticeship-to-work transition (second threshold; see Table 3) will be biased. The results of a bivariate probit model estimating the quality of transitions at both thresholds simultaneously dependent on the level of schooling are presented in Table 4.

-- please insert Table 4 about here -- 
The results of Equation I (determinants of a successful school-to-apprenticeship transition, operationalized in terms of selection into an apprenticeship with promising employment prospects; upper portion of Table 4) show that, in all three periods under investigation, whether or not an applicant was granted access to a "good" apprenticeship was largely determined by the quality of his or her general school-leaving certificate. Compared with the reference group of male school leavers holding at least a Realschule certificate, candidates from the Hauptschule - independent of their gender - were at a clear disadvantage when it came to choosing apprenticeship. In all three time periods, young women with a good level of general education had the best chances of being admitted to an apprenticeship with good employment prospects.

Equation II yields the main findings of this step in the analysis (determinants of a successful apprenticeship-to-work transition, operationalized as before in terms of an immediate transition to an adequate position; lower portion of Table 4). The pattern of results presented in Table 3, indicating that a low level of general education did not represent a risk factor until the most recent period of investigation (1975-1992) when there was a marked shift in the situation, remains unchanged even after controlling for what have been shown to be very strong selection effects in the allocation of candidates to apprenticeships. The results computed for the control variables are somewhat weaker than in the original model, but the general pattern holds. In other words, in the earlier periods of investigation (1948-1974), although lower-achieving school leavers were selected into less promising apprenticeships, a "poor" school-leaving certificate no longer had a detrimental effect at the second threshold - the apprenticeship-to-work transition. In the most recent period of observation, in contrast, the situation for lower academic achievers worsened dramatically: If school leavers with low levels of general education were able to find an apprenticeship at all, it was - as always - likely to be in an occupation with poor employment prospects. What has changed, however, is that a low level of schooling now also had an adverse effect at the second threshold, the apprenticeship-towork transition, even when controlling for the heterogeneity of the apprenticed trades/professions. It is clear that, in the most recent period of investigation, the dual system was no longer able to attain its objective of affording trainees (those in the same trades and professions, at least) equal opportunities on the labor market by certifying their competence in their chosen occupation.

What now needs to be explored is whether the crowding-out of trainees with lower levels of education occurs primarily in their traditional occupational sector or in the sector requiring higher levels of training. If the former were the case, this would imply, for example, that a hairdresser who atypically had a Realschule certificate would have better employment prospects than a fellow trainee with a Hauptschule certificate. In other words, Hauptschule leavers would face stiff competition in their traditional sector of the less demanding occupations. If, on the other hand, the latter were the 
case, it would mean that a Hauptschule graduate who atypically was capable of completing an apprenticeship in a bank could no longer count on his or her future employment prospects being determined by this most recently acquired and highest-level qualification alone. Such a development would be highly detrimental to the career opportunities of former Hauptschule students.

\section{Transitions from Different Sorts of Apprenticeships}

The results presented in Table 5 show that, until 1974, the quality of the school-leaving certificate acquired prior to the apprenticeship had no significant effect on the respondents' chances of realizing a successful apprenticeship-to-work transition in either the less demanding apprenticed trades or the more challenging professions. In the most recent period of investigation, however, there was a marked change in the pattern of results: Compared with their peers with apprenticeships in comparable occupations but higher levels of general education, Hauptschule leavers who atypically succeeded in completing an apprenticeship in an occupation with good employment prospects had significantly lower chances of later realizing a successful apprenticeship-to-work transition. In other words, the leveling-out effect of the apprenticeship qualification apparent in the first two periods of investigation has diminished. A somewhat weaker, but nonetheless significant effect can be observed in the sector of the less demanding apprenticed trades, where a higher school-leaving certificate still pays off in the long run for those with a good level of general education who atypically decide to serve this kind of apprenticeship. Here, again, former Hauptschule students of both genders are at an equal disadvantage.

-- please insert Table 5 about here --

Where the control variables are concerned, a fairly even picture emerges in all models. This reflects the clear division of the apprenticed trades/professions into those with "good" and "poor" employment prospects. With respect to the negative influence that the harsh economic situation in the most recent period of investigation was observed to have on the chances of realizing an optimal apprenticeship-to-work transition, however, it is worth noting that this development only hit those seeking jobs in the less demanding occupations, but that the effect here was highly significant. This, too, is an important result, confirming that the career prospects of less qualified applicants are more dependent on economic factors.

Comparison of the magnitude and strength of the schooling effects determined for former Hauptschule students in the models estimated for apprenticeships with "good" and "poor" employment 
prospects in the most recent time period shows that the crowding-out of newly qualified apprentices with low levels of schooling is more widespread in the more challenging sector than in the less demanding occupations. This might imply that within this more challenging domain (e.g., health care occupations and clerical occupations in banks, insurance companies, and public administration) job requirements in terms of vocational education and work experience are constantly rising, and that it is increasingly difficult for Hauptschule graduates to meet these demands. However, it is also conceivable that job requirements have in fact remained constant over time, but that the continuing expansion of the education system has led to increasing negative selection in the Hauptschule. This, too, would result in former Hauptschule students - even those with an apprenticeship in a more demanding occupation - having increasing difficulty in competing with fellow apprentices with higher levels of general education on the labor market. The fact that this crowding-out effect has even hit apprentices with lower levels of schooling in their traditional occupational sector of less demanding jobs - albeit to a lesser extent - should be a matter of concern for educational policymakers, as it raises the question of which functional training routes, if any, are still open to Hauptschule students. Although the rate of successful apprenticeship-to-work transitions is still reassuringly high, even for trainees with a Hauptschule certificate, this finding cannot conceal the fact that the components of human capital acquired in general education are becoming increasingly important on the German labor market. As an apprenticeship in the dual system is still the dominant form of vocational training in the non-academic domain in Germany, this realization should have farreaching implications for curriculum development at vocational schools.

\section{Summary and Conclusions}

The present study explored apprenticeship-to-work transitions using data from the 1991/92 wave of the BIBB/IAB employment survey. Respondents who secured a position corresponding to their qualifications immediately after completing their apprenticeship were deemed to have realized a successful transition. Particular attention was paid to developments in the prospects of former Hauptschule students over an extended time period (1948-1992).

The results show that the rate of successful transition is generally very high. In the most recent period of observation (1975-1992), however, trainees with only a Hauptschule certificate or no school-leaving certificate at all - irrespective of their gender - were significantly less likely to achieve a successful transition than their peers with a higher level of general education. This pattern of results holds when controlling for the occupation chosen, the characteristics of the firm providing the apprenticeship training, and the economic conditions prevailing at the time the apprenticeship 
was completed. Strikingly, the pattern even holds when controlling simultaneously for the systematic selection occurring at the transition from school to certain apprenticeships. The chances that trainees with lower levels of general education will realize a successful apprenticeship-to-work transition have decreased, both in their traditional occupational sector of the less demanding trades and in the more challenging (but non-academic) occupational sector.

From the perspective of human capital theory (Mincer 1974), in the 1948-1974 period, the components of human capital acquired in the course of the apprenticeship (vocational education and work experience) proved to be more important than those acquired in general education. From the perspective of signaling theory (Spence 1973), it can thus be concluded that the most recently acquired or highest-level qualification (namely the apprenticeship) was of particular importance in this period (for a examination of both of these theories, see Weiss 1995). The dual system was thus able to fulfill its objective of providing occupational certificates that afforded trainees equal opportunities on the labor market, irrespective of the level of general education acquired prior to the apprenticeship. Since 1975, this has no longer been the case. From the perspective of human capital theory, all components of human capital now seem to be of importance. The greater importance now attached to the components acquired in general education indicates that, in an increasingly complex world of work, employees are expected to have better cognitive qualifications, and that the dual system is no longer able to compensate for deficits in the domain of general education. From the perspective of signaling theory, all educational qualifications have now become relevant. In the course of the expansion of the education system, a poor school-leaving certificate has come to be regarded as the expression of negative selection; furthermore, this unfavorable signaling effect can no longer be completely offset by gaining a "good" apprenticeship in the dual system of vocational education.

It remains only to consider the implications of these findings for educational policy. Failure to respond to the finding that former Hauptschule students are becoming significantly less competitive on the labor market would assume that these students and their parents are aware that the increasing negative selection of Hauptschule students resulting from the expansion of the German education system incurs serious risks for those who are not capable of keeping up with the trend to higher levels of education. One possible response to these findings would be to enhance the quality of instruction in Hauptschulen. Another option would be to introduce new forms of training to the dual system, geared to Hauptschule leavers - for example, by setting up shorter or less demanding training programs in occupations with good employment prospects. Though it is clear that putting these recommendations into practice will require heavy investment in terms of both resources and time, it is safe to assume that failing to respond will, in the long run, incur far greater costs. 


\section{References}

Blossfeld, H.-P. 1985: Berufseintritt und Berufsverlauf. Eine Kohortenanalyse über die Bedeutung des ersten Berufs in der Erwerbsbiographie. In: Mitteilungen aus der Arbeitsmarkt- und Berufsforschung 18 (2), 177-197

Blossfeld, H.-P. 1988: Bildungsverläufe im historischen Wandel - Eine Längsschnittanalyse über die Veränderung der Bildungsbeteiligung im Lebenslauf dreier Geburtskohorten. In: Bodenhöfer, H.-J. (Ed.): Bildung, Beruf, Arbeitsmarkt. Series Schriften des Vereins für Socialpolitik, 174, Berlin, 259-302

Büchel, F. 1994: Overqualification at the Beginning of a Non-Academic Working Career - The Efficiency of the German Dual System under Test. In: Horn, G.-A. and Trabold, H. (Eds.): Globalisation and Structural Unemployment. Special Issue of Konjunkturpolitik 40 (3-4), 342-368

Büchel F. 2001. Overqualification: Reasons, measurement issues and typological affinity to unemployment. In: Descy P. and Tessaring M. ( CEDEFOP; Eds.), Training in Europe. Second report on vocational training research in Europe 2000. Background Report, Vol. 2, Luxembourg, 453-560.

Büchel, F. and Neubäumer, R. (forthcoming): Individuelle Berufschancen als Folge branchenspezifischer Ausbildungsstrategien. In: Mitteilungen aus der Arbeitsmarkt- und Berufsforschung

Büchtemann, C. F., Schupp, J. and Soloff, D. J. 1994: From school to work: patterns in Germany and the United States. In: Schwarze, J., Buttler, F. and Wagner, G. G. (Eds.): Labour market dynamics in present day Germany, Frankfurt am Main, 112-141

Burgess, S., Propper, C., Rees, H. and Shearer, A. 1999: The class of '81: The effects of early-career unemployment on subsequent unemployment experiences. CASEpaper No. 32, London

Franz, W. and Soskice, D. 1995: The German Apprenticeship System. In: Buttler, F., Franz, W., Schettkat, R., and Soskice, D. (Eds.): Institutional Frameworks and Labor Market Performance, Nürnberg, 208-Xxx

Gangl, M. 2000: Changing labour markets and early career outcomes: Labour market entry in Europe over the past decade. MZES Working paper No. 26, 2000, Mannheim

Gitter, R. J. and Scheuer, M. 1997: US and German youths: unemployment and the transition from school to work. In: Monthly Labor Review, 120 (3), 16-20

Greene, W. H. 2000: Econometric Analysis. Fourth Edition. New Jersey

Hamilton, S. E. and Hamilton, M. A. 1999: Creating new pathways to adulthood by adapting German apprenticeship in the United States. In: Heinz, W. R. (Ed.): From education to work: cross-national perspectives, Cambridge UK

Handl, J. 1996: Hat sich die berufliche Wertigkeit der Bildungsabschlüsse in den achtziger Jahren verringert? Eine Analyse der abhängig erwerbstätigen, deutschen Berufsanfänger auf der Basis von Mikrozensusergebnissen. In: Kölner Zeitschrift für Soziologie und Sozialpsychologie, 48 (2), 249273

Harhoff, D. and Kane, T. J. 1997: Is the German apprenticeship system a panacea for the US labor'market? In: Journal of Population Economics, 10 (2), 171-196

Helberger, C., Rendtel, U. and Schwarze, J. 1994: Labour market entry of young people analysed by a double threshold model. In: Zapf, W., Schupp, J. and Habich, R. (Eds.): Labour market dynamics in present day Germany, Frankfurt am Main, 142-164

Inkmann, J., Klotz, S.and Pohlmeier, W. 1998: Growing into work - Pseudo panel data evidence on labor market entrance in Germany. ZEW Discussion Paper 98-47, Mannheim

Jansen, R. and Stooß, F. 1993: Qualifikation und Erwerbssituation im geeinten Deutschland. Ein Überblick über die Ergebnisse der BIBB/IAB-Erhebung 1991/92, Berlin and Bonn

Konietzka, Dirk 1999: Ausbildung und Beruf. Die Geburtsjahrgänge 1919 - 1961 auf dem Weg von der Schule in das Erwerbsleben, Opladen

Klotz, S., Pohlmeier, W. and Inkmann, J. 2000:Langfristige Folgen eines missglückten Übergangs von der Lehre in den Beruf. In: Büchel, F., Diewald, M., Krause, P., Mertens, A. and Solga, H. (Eds.): Zwischen drinnen und draussen : Arbeitsmarktchancen und soziale Ausgrenzungen in Deutschland, Opladen, 53-62 
Kühn, T. and Zinn, J. 1998: Zur Differenzierung und Reproduktion sozialer Ungleichheit im Dualen System der Berufsausbildung. Quantitative und qualitative Ergebnisse einer Verlaufsuntersuchung über junge Erwachsene in sechs Ausbildungsberufen. In: Heinz, W. R., Dressel, W., Blaschke, D., Engelbrech, G. (Eds.): Was prägt Berufsbiographien? Beiträge zur Arbeitsmarkt- und Berufsforschung, Vol. 213, 54-88

Mincer, Jacob 1974: Schooling, Experience, and Earnings. New York.

Müller, W., Steinmann, S. and Ell, R. 1998: Education and labour-market entry in Germany. In: Shavit, Y. and Müller, W. (Eds.): From school to work, Oxford, 143-188

Neubäumer, R. 1999: Der Ausbildungsstellenmarkt der Bundesrepublik Deutschland. Eine theoretische and empirische Analyse. Berlin

Ní Cheallaigh, M. (CEDEFOP) 1995: Apprenticeship in the EU member states - A comparison. Luxembourg

OECD 2000 (Ed.): Education at a Glance: OECD Indicators 2000 Edition, Paris

Palamidis, H. and Schwarze, J. 1989: Jugendliche beim Übergang in eine betriebliche Berufsausbildung und in die Erwerbstätigkeit. In: Mitteilungen aus der Arbeitsmarkt- und Berufsforschung, 22 (1), 114-124

Raffe, D. 1997: The 'transition from school to work' and its heirs - An analysis of a changing research field. In: Jobert, A., Marry, C., Tanguy, L. and Rainbird, H. (Eds.): Education and work in Great Britain, Germany and Italy, London and New York, 128-142

Shavit, Y. and Müller, W. 1998 (Eds.): From school to work, Oxford

Soskice, D. 1994: Reconciling Markets and Institutions: The German Apprenticeship System, in: Lynch, L.M. (Ed.) 1994: Training and The Private Sector. International Comparisons, Chicago, 25-xxx

Spence, M. 1973: Job Market Signalling. In: Quarterly Journal of Economics, 87, 355-374

Tessaring, M. 1993: Das duale System der Berufsausbildung in Deutschland: Attraktivität und Beschäftigungsperspektiven. Ein Beitrag zur gegenwärtigen Diskussion. In: Mitteilungen aus der Arbeitsmarkt- und Berufsforschung, 26 (2), 131-161

Weiss, A. M. 1995: Human capital vs. Signaling Explanations of Wages. In: Journal of Economic Perspectives, 9 (4), 133-154

Winkelmann, R. 1996: Employment prospects and skill acquisition of apprenticeship-trained workers in Germany. In: Industrial and Labor Relations Review, 49 (4), 658-672 
Table 1: Transitions from completed apprenticeship to work, by time period and first employment status, in $\frac{0}{0}$ (West Germany, 1948 - 1992)

$$
\begin{aligned}
& \text { Year of completing apprenticeship: } \\
& \text { 1948-1959 1960-1974 1975-1992 }
\end{aligned}
$$

First employment

status after completing

apprenticeship:

Adequate position

89

89

86

Overqualified position

10

10

10

Unemployed

100

100

$\mathrm{N}$ of cases

2560

4401

5469

Only persons employed at time of interview (1991/92).

Foreigners and those few respondents who acquired a university degree before starting an apprenticeship were excluded.

Only persons belonging to the economically active population immediately after completing their apprenticeship (those going on to further education, doing military/community service, or in voluntary unemployment were excluded).

Weighted frequencies; unweighted number of cases.

Source: Own calculations based on data from the BIBB/IAB Employment Survey, $1991 / 1992$. 
Table 2 :

Transitions from completed apprenticeship to work, by time period, gender, previous schooling, and first employment status, in $\frac{\circ}{0}$ (West Germany, 1948 1992)

Year of completing apprenticeship:

$$
\text { 1948-1959 1960-1974 1975-1992 }
$$

First employment status after completing apprenticeship:

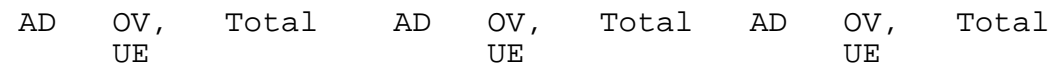

Schooling prior

to apprenticeship:

Hauptschule certificate or lower ("poor schooling")

$\begin{array}{llllllllll}\text { Men } & 90 & 10 & 100 & 90 & 10 & 100 & 83 & 17 & 100 \\ \text { Women } & 88 & 12 & 100 & 87 & 13 & 100 & 81 & 19 & 100\end{array}$

Realschule certificate or higher ("good schooling")

\begin{tabular}{|c|c|c|c|c|c|c|c|c|}
\hline Men & 87 & 13 & 100 & 90 & 10 & 100 & 90 & 10 \\
\hline Women & 91 & 9 & 100 & 92 & 8 & 100 & 89 & 11 \\
\hline
\end{tabular}

$\mathrm{N}$ of cases:

Hauptschule certificate or lower

\begin{tabular}{|c|c|c|c|}
\hline $\begin{array}{l}\text { Men } \\
\text { Women }\end{array}$ & $\begin{array}{r}1627 \\
464\end{array}$ & $\begin{array}{r}2087 \\
930\end{array}$ & $\begin{array}{r}1765 \\
783\end{array}$ \\
\hline Realsc & & & \\
\hline $\begin{array}{l}\text { Men } \\
\text { Women }\end{array}$ & $\begin{array}{l}324 \\
145\end{array}$ & $\begin{array}{l}825 \\
559\end{array}$ & $\begin{array}{l}1368 \\
1553\end{array}$ \\
\hline Total & 2560 & 4401 & 5469 \\
\hline
\end{tabular}

$\mathrm{AD}$ : Adequate position ("successful transition" in view of previous training)

OV: Overqualified position, UE: Unemployment ("unsuccessful transition" in view of previous training).

Only persons employed at time of interview (1991/92).

Foreigners and those few respondents who acquired a university degree before starting an apprenticeship were excluded.

Only persons belonging to the economically active population immediately after completing the apprenticeship (those going on to further education, doing military/community service, or in voluntary unemployment were excluded).

Weighted frequencies; unweighted number of cases.

Source: Own calculations based on data from the BIBB/IAB Employment Survey, $1991 / 1992$. 
Table 3: Determinants of a successful apprenticeship-to-work transition, by time period (binary probit models, West Germany, $1948-1992)$

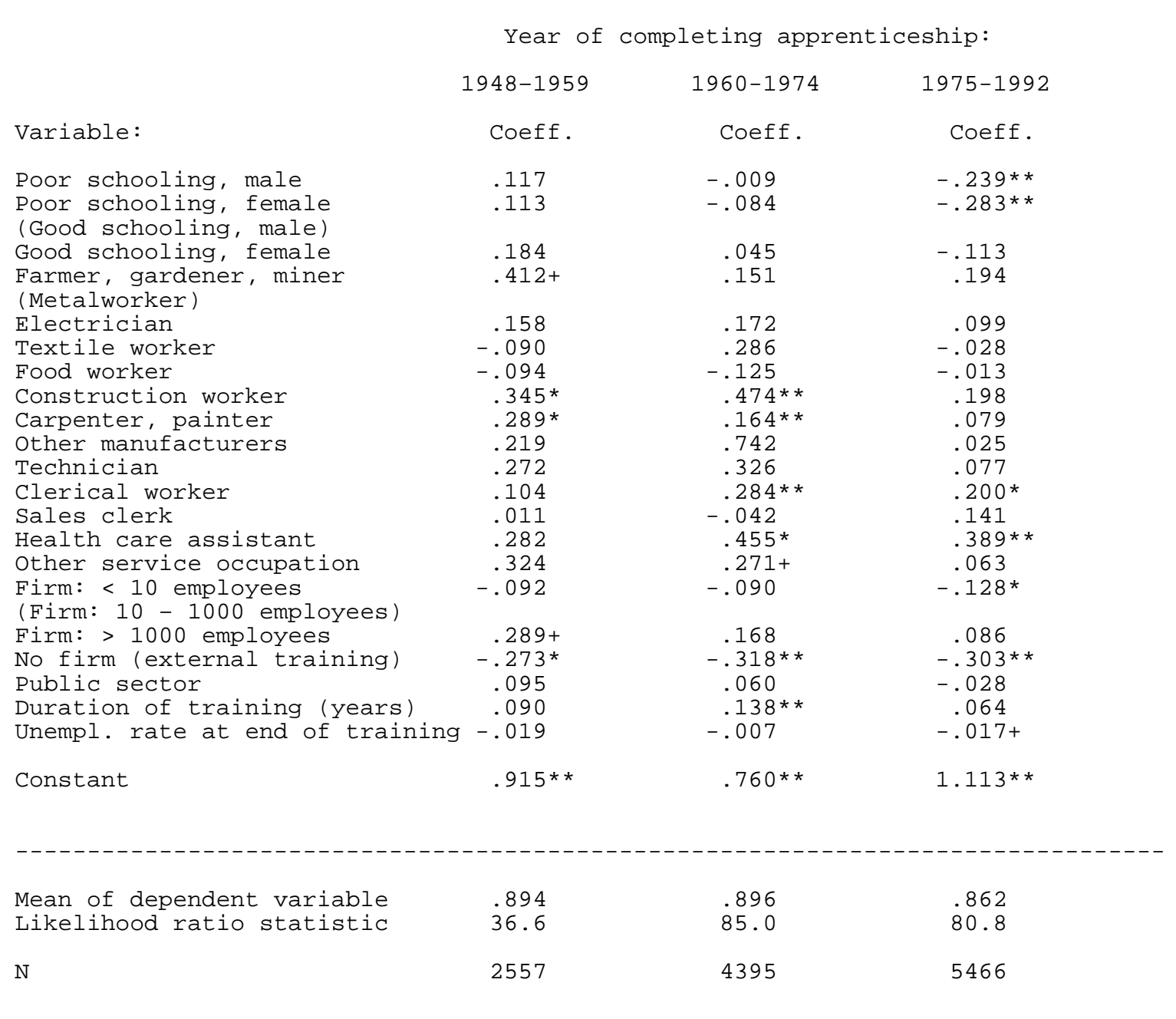

Significance levels: $\star \star(\mathrm{p}<.01), \star(\mathrm{p}<.05),+(\mathrm{p}<.10)$.

Dependent variable: 1 = "successful" apprenticeship-to-work transition (immediate move to adequate position); 0 = "unsuccessful" transition (move to overqualified position or unemployment).

Only persons employed at time of interview (1991/92).

Foreigners and those few respondents who acquired a university degree before starting an apprenticeship were excluded.

Only persons belonging to the economically active population immediately after completing the apprenticeship (those going on to further education, doing military/community service, or in voluntary unemployment were excluded).

Source: Own calculations based on data from the BIBB/IAB Employment Survey, $1991 / 1992$. 
Table 4:

Combined determinants of first entering an apprenticeship with good employment prospects and later realizing a successful apprenticeship-to-work transition, by time period (bivariate probit models (FIML), West Germany, 1948 1992)

Year of completing apprenticeship:

1948-1959 1960-1974 1975-1992

Variable:

Coeff.

Coeff.

Coeff.

Equation I:

(Determinants of entering an apprenticeship with "good" employment prospects)

\begin{tabular}{|c|c|c|c|}
\hline Poor schooling, male & $-.190 *$ & $-.395 * \star$ & $-.670 * \star$ \\
\hline Poor schooling, female & $-.393 * \star$ & $-.746 * \star$ & $-.626 * \star$ \\
\hline $\begin{array}{l}\text { (Good schooling, male) } \\
\text { Good schooling, female }\end{array}$ & $(.525 * *$ & $(.258 * *$ & $(.361 * *$ \\
\hline Constant & .069 & $.212 * \star$ & $.082 *$ \\
\hline
\end{tabular}

Equation II:

(Determinants of later realizing a "successful" apprenticeship-to-work transition)

Poor schooling, male

Poor schooling, female

(Good schooling, male)

Good schooling, female

.123

.126

(. 169$)$

$-.013$

$-.090$

.169

$(.04)$

Farmer, gardener, miner

.482

(Metalworker)

Electrician

Textile worker

$(.0)$

$-.091$

Food worker

Construction worker

Carpenter, painter

Other manufacturers

$-.095$

.417

$.362 *$

.219

.341

Clerical worker

Sales clerk

.174

.011

.349

Health care assistant

Other service occupation

.395

$-.093$

(Firm: $10-1000$ employees)

Firm: > 1000 employees

(. $)$

$.289+$

$-.310+$

.098

Public sector

.091

Unempl. rate (end of train.) -.019

Constant

$\mathrm{RHO}$ ( I, II)

$.874 \star \star$

.048

.131

(. $)$

.151

.286

$-.125$

$.453+$

.143

.722 *

.306

.264 *

$-.042$

$.436+$

.271

$-.090$

(. $)$

.168

$-.306 *$

.060

$.138 * *$

$-.007$

$-.302 * \star$

(. )

.102

.114

$(.01)^{2}$

.019

$-.028$

$-.011$

.0118

.078

.023

.023

.122

.140

$.316+$

.061

-.127 *

(. )

.086

.086
$-.254 *$

$-.027$

.027
.064

.064
$-.017+$

RHO $(I, I I)$

2557

$.771^{\star *}$

1.151 *

.051

N

$-.013$

Dep. mean of Equation I

Dep. mean of Equation II

Log-L

.151
.894
-1911.5

2557
5466

4395

.336

.862

$-4888.7$

$-4201.9$

4395

5466

Significance levels: ** $(\mathrm{p}<.01), *(\mathrm{p}<.05),+(\mathrm{p}<.10)$.

Dependent variable of Equation I: 1 = Having completed a type of apprenticeship with "good" employment prospects; 0 = other.

Apprenticeships with "good" employment prospects: In all three periods: primary sector occupations; electricians; construction workers; technicians; clerical workers in banks, insurance agencies, and public administration; health care occupations (in all cases: if apprenticeship served in company authorized to provide apprenticeship training). Additionally for 1948-1959 period: carpenters, painters; other service occupations. Additionally for 1960-1974 period: carpenters, painters; other manufacturers. See text for information on the selection procedure. 
Dependent variable of Equation II: 1 = "successful" apprenticeship-to-work transition (immediate move to adequate position); $0=$ "unsuccessful" transition (move to overqualified position or unemployment).

Only persons employed at time of interview (1991/92).

Foreigners and those few respondents who acquired a university degree before starting an apprenticeship were excluded.

Only persons belonging to the economically active population immediately after completing the apprenticeship (those going on to further education, doing military/community service, or in voluntary unemployment were excluded).

Source: Own calculations based on data from the BIBB/IAB Employment Survey, $1991 / 1992$. 
Table 5

Determinants of realizing a successful apprenticeship-to-work transition, by time period (selected types of apprenticeships, binary probit models, West Germany, 1948 - 1992)

Year of completing apprenticeship:
$1948-1959$
$1960-1974$
$1975-1992$

Type of apprenticeship (indicated by employment prospects):

Variable:

Poor schooling, male

Poor schooling, female

(Good schooling, male)

Good schooling, female

Farmer, gardener, miner

(Metalworker)

Electrician

Textile worker

Food worker

Construction worker

Carpenter, painter

other manufacturers

Technician

Clerical worker

Sales clerk

Health care assistant

Other service occupation

Firm: < 10 employees

(Firm: 10-1000 employees)

Firm: > 1000 employees

No firm (external training)

Public sector

Duration of training (years)

Unempl.rate at end of train.

Constant

Mean of dependent variable

Likelihood ratio statistic

$\mathrm{N}$

$.918 \quad .873$

$8.6 \quad 17.2$

$1184 \quad 1376$

$\left.\begin{array}{cc}.010 & .191 \\ .050 & .159 \\ .161 & (.\end{array}\right)$

.212

.053

(. )

$-.073$

$-.085$

$.335+$

.151

.349

(. $)$

$$
.209
$$

.182

.214

.070

(.

.337

.107

.078

$-.012$

\section{.023}

\begin{abstract}
good
poor
\end{abstract}

good

poor

Coeff. Coeff. Coeff. Coeff.

Coeff. Coeff.

$.065 \quad .054$

$-.026-.119$

$-.006$

(.

$-.333 * *-.183 *$

$-.332 * \star-.210 *$

$-.332 * x)(.0)$

$-.171+-.006$

$-.005$

$-.135$

(. )

$-.028$

$-.186$

.079

$-.164$

.159

$-.187$

.327

.090

(.)

.130

$-.156$

$.139 . .186$

$(.139)$

$-.061$

.041

(. )

$.376 *$
$-.212 *$

$-.212$

$.113-.029$

104

$-.010$

.029

1.213 * 1.245 *

$.946 * * 1.409 * *$

$.158 *-.004$

$.009-.034 * *$

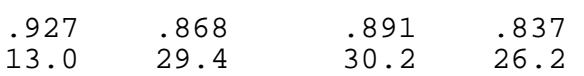

$30.2 \quad 26.2$

Significance levels: ** $(\mathrm{p}<.01), *(\mathrm{p}<.05),+(\mathrm{p}<.10)$.

Types of apprenticeship with "good" or "poor" employment prospects are gained from weighted crosstabs (time period * type of apprenticeship * success of apprenticeship-towork transition).

Apprenticeships with "good" employment prospects: In all three periods: primary sector occupations; electricians; construction workers; technicians; clerical workers in banks, insurance agencies, and public administration; health care occupations (in all cases: if apprenticeship served in company authorized to provide apprenticeship training). Additionally for 1948-1959 period: carpenter, painter; other service occupations. Additionally for 1960-1974 period: carpenter, painter; other manufacturers. See text for information on the selection procedure.

Dependent Variable: 1 = "successful" apprenticeship-to-work transition (immediate move to adequate position); $0=$ "unsuccessful" transition (move to overqualified position or unemployment).

Only persons employed at time of interview (1991/92).

Foreigners and those few respondents who acquired a university degree before starting an apprenticeship were excluded.

Only persons belonging to the economically active population immediately after completing the apprenticeship (those going on to further education, doing military/community service, or in voluntary unemployment were excluded).

Source: Own calculations based on data from the BIBB/IAB Employment Survey, 1991/1992. 
Appendix Table: Unweighted Means of Covariates Used in Equation II, Table 4 .

Poor schooling, male

Poor schooling, female

(Good schooling, male)

Good schooling, female

Farmer, gardener, miner

(Metalworker)

Electrician

Textile worker

Food worker

Construction worker

Carpenter, painter

other manufacturers

Technician

Clerical worker

Sales clerk

Health care assistant

Other service occupation

Firm: < 10 employees

(Firm: 10-1000 employees)

Firm: > 1000 employees

No firm (external training)

Public sector

Duration of training (years)

Unempl. rate at end of training

Year of Completing Apprenticeship:

$\begin{array}{ccc}1948-1959 & 1960-1974 & 1975-1992 \\ .635 & .474 & .322 \\ .181 & .211 & .142 \\ .056 & .127 & .284 \\ .039 & .021 & .021 \\ .044 & .076 & .069 \\ .051 & .026 & .014 \\ .045 & .033 & .035 \\ .078 & .036 & .036 \\ .096 & .044 & .042 \\ .038 & .028 & .030 \\ .017 & .031 & .027 \\ .169 & .225 & .259 \\ .127 & .160 & .133 \\ .021 & .043 & .040 \\ .024 & .037 & .289 \\ .402 & .299 & .107 \\ .073 & .087 & .079 \\ .055 & .076 & .139 \\ .064 & .099 & .916 \\ .035 & .068 & 5466 \\ 5.950 & 1.142 & .741 \\ 2557 & 4395 & \end{array}$

Source: Own calculations based on data from the BIBB/IAB Employment Survey, $1991 / 1992$. 


\section{IZA Discussion Papers}

\begin{tabular}{|c|c|c|c|c|}
\hline No. & Author(s) & Title & Area & Date \\
\hline 410 & $\begin{array}{l}\text { H. Lehmann } \\
\text { J. Wadsworth }\end{array}$ & $\begin{array}{l}\text { Wage Arrears and the Distribution of Earnings in } \\
\text { Russia }\end{array}$ & 4 & $12 / 01$ \\
\hline 411 & S. Stillman & $\begin{array}{l}\text { The Response of Consumption in Russian } \\
\text { Households to Economic Shocks }\end{array}$ & 4 & $12 / 01$ \\
\hline 412 & $\begin{array}{l}\text { M. Barbie } \\
\text { M. Hagedorn } \\
\text { A. Kaul }\end{array}$ & $\begin{array}{l}\text { Government Debt as Insurance against } \\
\text { Macroeconomic Risk }\end{array}$ & 7 & $12 / 01$ \\
\hline 413 & $\begin{array}{l}\text { H. Bonin } \\
\text { R. Euwals }\end{array}$ & $\begin{array}{l}\text { Participation Behavior of East German Women } \\
\text { after German Unification }\end{array}$ & 1 & $12 / 01$ \\
\hline 414 & $\begin{array}{l}\text { A. Frederiksen } \\
\text { N. Westergaard- } \\
\text { Nielsen }\end{array}$ & Where Did They Go? & 1 & $01 / 02$ \\
\hline 415 & $\begin{array}{l}\text { M. Bertrand } \\
\text { F. Kramarz }\end{array}$ & $\begin{array}{l}\text { Does Entry Regulation Hinder Job Creation? } \\
\text { Evidence from the French Retail Industry }\end{array}$ & 6 & $01 / 02$ \\
\hline 416 & $\begin{array}{l}\text { B. Crépon } \\
\text { F. Kramarz }\end{array}$ & $\begin{array}{l}\text { Employed } 40 \text { Hours or Not-Employed 39: } \\
\text { Lessons from the } 1982 \text { Mandatory Reduction of } \\
\text { the Workweek }\end{array}$ & 6 & $01 / 02$ \\
\hline 417 & J. Wagner & $\begin{array}{l}\text { Taking a Second Chance: } \\
\text { Entrepreneurial Restarters in Germany }\end{array}$ & 1 & $01 / 02$ \\
\hline 418 & $\begin{array}{l}\text { M. Frölich } \\
\text { P. A. Puhani }\end{array}$ & $\begin{array}{l}\text { Immigration and Heterogeneous Labor in } \\
\text { Western Germany: A Labor Market } \\
\text { Classification Based on Nonparametric } \\
\text { Estimation }\end{array}$ & 2 & $01 / 02$ \\
\hline 419 & $\begin{array}{l}\text { P. Frijters } \\
\text { J. P. Haisken-DeNew } \\
\text { M. A. Shields }\end{array}$ & $\begin{array}{l}\text { The Value of Reunification in Germany: } \\
\text { An Analysis of Changes in Life Satisfaction }\end{array}$ & 6 & $01 / 02$ \\
\hline 420 & $\begin{array}{l}\text { Å. Rosén } \\
\text { E. Wasmer }\end{array}$ & $\begin{array}{l}\text { Higher Education Levels, Firms' Outside Options } \\
\text { and the Wage Structure }\end{array}$ & 1 & $01 / 02$ \\
\hline 421 & P. Manzini & Divide et Impera: Negotiating with a Stakeholder & 6 & $02 / 02$ \\
\hline 422 & $\begin{array}{l}\text { J. T. Addison } \\
\text { L. Bellmann } \\
\text { C. Schnabel } \\
\text { J. Wagner }\end{array}$ & $\begin{array}{l}\text { The Long Awaited Reform of the German Works } \\
\text { Constitution Act }\end{array}$ & 6 & $02 / 02$ \\
\hline 423 & $\begin{array}{l}\text { E. Feess } \\
\text { G. Muehlheusser }\end{array}$ & Transfer Fee Regulations in European Football & 1 & $02 / 02$ \\
\hline 424 & $\begin{array}{l}\text { F. Büchel } \\
\text { M. van Ham }\end{array}$ & $\begin{array}{l}\text { Overeducation, Regional Labour Markets and } \\
\text { Spatial Flexibility }\end{array}$ & 3 & $02 / 02$ \\
\hline 425 & F. Büchel & $\begin{array}{l}\text { Successful Apprenticeship-to-Work Transitions: } \\
\text { On the Long-Term Change in Significance of the } \\
\text { German School-Leaving Certificate }\end{array}$ & 3 & $02 / 02$ \\
\hline
\end{tabular}

